\title{
THE EFFECT OF INSTITUTIONAL AND CULTIVATION INNOVATIONS ON THE PERFORMANCE OF RICE ESTATE COMMUNITIES IN PURBALINGGA DISTRICT, MALANG DISTRICT, AND MUSI BANYUASIN DISTRICT
}

\author{
Dr. Ir Amiruddin Saleh ${ }^{1}$, Dr. Ir Johan David Wetik ${ }^{2}$, Pallahudin Se.Me ${ }^{3}$ \\ ${ }^{1}$ Faculty of Human Ecology IPB-University, Indonesia \\ ${ }^{2}$ Kalpataru Businness School, Indonesia \\ ${ }^{3}$ Faculty of Economic Djuanda University, Indonesia
}

DOI: 10.46609/IJSSER.2021.v06i07.001 URL: https://doi.org/10.46609/IJSSER.2021.v06i07.001

\begin{abstract}
This research is part of the implementation of the rice farming institutional model "Rice Estate Community (REC)." This study aims to determine the effect of farmers' institutional formation and innovation of rice farming cultivation on REC performance in three research locations, namely Purbalingga District, Malang District and Musi Banyuasin District. This study used a survey method on 16 respondents in Malang District, 28 respondents in Purbalingga District and 16 respondents in Musi Banyasin District. Respondents were taken using purposive sampling technique from a population of prospective farmers of 101 hectares on the island of Java and 303 hectares outside of Java. The results showed that the perception of the formation of REC Institutions in Musi Banyuasin District was better than that of Purbalingga District and Malang District. Perception of Rice Cultivation Innovation in Malang District is better than Purbalingga District and Musi Banyuasin District. Perceptions of the performance of REC, Malang District and Musi Banyuasin District are better than Purbalingga District. Partially, the institutional effect on the performance of REC has the highest contribution in Musi Banyuasin District, 24.9\%. Partially the effect of cultivation innovation on the performance of REC, the highest contribution in Malang District is $73.6 \%$.
\end{abstract}

\section{Introduction}

The productivity of rice plants in Indonesia is still very potential to be increased to more than 10 tons of GKP per ha through the application of good agricultural practices (GAP) covering aspects of technology and appropriate management. The use of quality agroinputs, appropriate dosages and techniques, appropriate and environmentally friendly pest and disease control. Land management that fertilizes and nourishes the soil is a component of GAP that needs to be 


\section{International Journal of Social Science and Economic Research}

ISSN: $2455-8834$

Volume:06, Issue:07 "July 2021"

implemented in order to achieve high productivity. In addition to productivity, it is also necessary to increase the efficiency of the cultivation process through the application of agricultural mechanization, namely the use of agricultural machinery in cultivation practices such as tractors, planters, harvesters, trashers, and others.

In addition to technology and management, it is also necessary to develop farming institutions as a means of learning (knowledge transfer) and joint efforts to strengthen the bargaining position (bargaining position) in a professional collective effort. Lowland rice farming is currently dominated by farmers with narrow land ownership. Any efforts made to farmers on a narrow scale will not be able to improve the welfare of farmers. This is because farming does not meet the minimum economies of scale.

Ownership of narrow land will also make it difficult to implement mechanization, low motivation of farmers in the use of high quality seeds, and inefficient farming management. In addition, the narrow land fragmentation also causes the planting not to be simultaneous. This has a negative impact on the risk of pests and diseases because there are always crops in the field with various stages of growth. In addition, the government encourages continuous rice cultivation throughout the year in order to meet the increasing demand for rice in line with rapid population growth. It also contributes to the risk of pests and diseases. This problem if left unchecked can reduce the ability of farmers to carry out agricultural production. This can be an obstacle to the achievement of national food security.

Therefore, it is very important to consolidate the agricultural system. So that farming becomes more efficient and profitable as well as the welfare of farmers. With a wider scale, then mechanization can be done. The harvest can be further processed into rice. By-products such as groats, rice bran, husks and others can be processed and sold with better economic value. The motivation for technology adoption will increase, including the use of high-quality seeds from high-yielding varieties, which are still low $(<50 \%)$.

In the current industrial era 4.0, IPB University also encourages the development and application of intelligent agrosystems in production systems to marketing agricultural products. Which smart system to develop is prioritized according to the needs of the farming community. In its implementation it will be very effective if the intelligent system technology is transferred through a solid institution (not individuals) because intelligent system technology requires insight, a higher level of knowledge and skills. Farmer Institutions (REC) are expected to be able to accept, apply and disseminate the technology to its member farmers.

Research activities (action research) that are packaged simultaneously with the dissemination of research results are more effective and efficient for the downstreaming and adoption of research 


\section{International Journal of Social Science and Economic Research}

ISSN: $2455-8834$

Volume:06, Issue:07 "July 2021"

results by the community. This research is part of the implementation of the rice farming institutional model "Padi Estate Community (REC)." This research aims to determine the effect of farmer institutional formation and innovation of rice farming cultivation on REC performance in three research locations, namely Purbalingga District, Malang District and Musi Banyuasin District.

\section{Method}

The research is divided into four sub-activities, namely: 1) Development of production technology; 2) Institutional strengthening and assistance; 3) Development of collective business (start up) together; 4) Development and application of intelligent agrosystems. The activity started with (1) observation base study on the potential of rice farmer groups and survey methods on 16 respondents in Malang District, 28 respondents in Purbalingga District and 16 respondents in Musi Banyasin District. The sampling of respondents as a sample used purposive sampling from a population of prospective farmers of 101 hectares on the island of Java and 303 hectares outside the island of Java; (2) introduce REC institutional innovations in rice farming until the REC institution is formed, which is characterized by declaration activities; (3) Training, counseling and mentoring; and (4) conduct monitoring and evaluation (Monev). In the first year (2020 - 2021) the motivation for establishing and strengthening REC is strengthened by (1) Strengthening rice farming institutions (REC) with legal entities, (2) Building a 6-hectare rice production demonstration farm in different areas, (3) Business startups collectively as an information technology-based company (start up), (4) Development/application of intelligent agrosystem technology.

The research was carried out from August 2020 to May 2021 in three districts, namely Kanigoro Village, Pagelaran District, Malang District, Penolih Village, Kaligondang District, Purbalingga District and Karya mukti Village, Lalan District, Musi Banyuasin District. Data collection techniques through questionnaire interviews, in-depth interviews, and focus group discussions. Data analysis used partial least squares (PLS) statistical analysis, and different tests.

\section{Results and Discussion}

\section{Characteristics of Respondents for Rice Farmers}

The characteristics of the responses of rice farmers from the three research areas are as shown in table 1. All research areas show that the majority are male. In contrast to the village monograph data, the total population of Kanigoro village, Malang District is 11,242 people, consisting of 5,481 men and 5,761 women. The total population of Penolih village, Purbalingga District is 3,725 people ( 1,893 men and 1,832 women). 
International Journal of Social Science and Economic Research

ISSN: 2455-8834

Volume:06, Issue:07 "July 2021"

Table 1. Data on Respondents of Rice Farmers in Purbalingga, Malang, and Musi Banyuasin Regencies

\begin{tabular}{|c|c|c|c|}
\hline Farmer Characteristics & $\begin{array}{l}\text { Purbalingga } \\
(\%)\end{array}$ & $\begin{array}{c}\text { Malang } \\
(\%)\end{array}$ & $\begin{array}{c}\text { Musi } \\
\text { Banyuasin } \\
(\%)\end{array}$ \\
\hline \multicolumn{4}{|l|}{ Gender } \\
\hline - Man & 89 & 81 & 100 \\
\hline - Woman & 11 & 19 & 0 \\
\hline \multicolumn{4}{|l|}{ Age } \\
\hline $22-32$ & 0 & 0 & 56 \\
\hline $33-44$ & 18 & 31 & 25 \\
\hline $45-54$ & 29 & 56 & 19 \\
\hline $55-64$ & 36 & 6 & 0 \\
\hline 65-74 & 18 & 6 & 0 \\
\hline \multicolumn{4}{|l|}{ Last Education } \\
\hline Primary School & 61 & 44 & 38 \\
\hline Junior High School & 18 & 6 & 13 \\
\hline Senior High School & 21 & 44 & 38 \\
\hline Bachelor & 0 & 6 & 13 \\
\hline \multicolumn{4}{|l|}{ Ownership status } \\
\hline Cultivator & 36 & 25 & 0 \\
\hline Owner & 7 & 0 & 19 \\
\hline Both & 57 & 75 & 81 \\
\hline \multicolumn{4}{|l|}{ Cultivated Land Area } \\
\hline$(\mathrm{Ha})$ & 61 & 75 & 0 \\
\hline $0,07-0,33$ & 29 & 6 & 0 \\
\hline $0,34-0,66$ & 11 & 19 & 0 \\
\hline $0,67-1,00$ & 0 & 0 & 44 \\
\hline $1,01-2,00$ & 0 & 0 & 38 \\
\hline $2,01-3,00$ & 0 & 0 & 19 \\
\hline
\end{tabular}

For age in Purbalingga District and Malang District, the largest percentage is still in the age range of 33 to 54 years, except for the Musi Banyuasin area in the relatively young range of 22 to 32 years. In addition, in terms of education, Musi Banyuasin District also shows a large percentage of higher education, compared to Purbalingga District and Malang District.

All farmers were classified into unproductive labor age group as indicated the farmer did not have any personal life insurance, mainly as they getting old. The farmers still had to work in the old age as stated by Andini et al. (2013) because they did not have any insurances. The characterisitics of farmer's educational attainment according to Manyamsari and Mujiburrahmad 
International Journal of Social Science and Economic Research

ISSN: 2455-8834

Volume:06, Issue:07 "July 2021"

(2014) will effect the farmer's competence to do the agricultural practices. The low farmer's educational attainment will cause poor ability in planning and coordination as mentioned by Suyanto and Khususiyah (2006).

The status of arable land ownership, in all research areas, shows the largest percentage both as owners and as cultivators of their own land. The area of arable land for Java Island (Purbalingga District and Malang District) is under one hectare, while Musi Banyuasin District has the largest percentage of arable area above one hectare. The condition of the land on Sumatra Island in Karya Mukti Village, Musi Banyuasin District is very different from that on Java Island, which is part of the swamp land classified as tidal swamp. Farmers in Karya Mukti village are transmigrant farmers mostly from Bali and West Java.

\section{Results of Different Perceptions of Institutional Establishment}

The results of the different perception test of the institutional formation of REC rice farmers between the three districts are shown in table 2. In terms of institutional variables, the average Musi Banyuasin District is the highest compared to Malang District and Purbalingga District and is significantly different. For indicators of terms and vision and mission, there is no difference between Purbalingga District and Malang District. This indicator is also asked about the name of the REC that motivates, the flow chart of the functions and objectives of the REC, as well as the Partnership in the REC. Indicators of the organizational structure of the REC, the Malang District average is not different from the Musi Banyuasin District average. In this indicator, the instruments questioned are group leadership, division of work tasks, and membership system.

Five aspects of the dynamical aspects of the institutional were assessed including goals, compactness, task function, atmosphere and group pressure. The goal was the most important component in building and maintaining a group, because a common goal would produce commitment within a group(Slamet,2002).

Table 2 of Differences in Institutional Perceptions between Purbalingga District and Malang District and Banyuasin District

\begin{tabular}{cccc}
\hline Variables And Indicators & $\begin{array}{c}\text { Purbalingga } \\
\text { Mean Score }\end{array}$ & $\begin{array}{c}\text { Malang } \\
\text { Mean Score }\end{array}$ & $\begin{array}{c}\text { Musi } \\
\text { BanyuasinMean } \\
\text { Score }\end{array}$ \\
\hline $\begin{array}{l}\text { Institutional } \\
-\quad \text { Terms And }\end{array}$ & $6.6 \mathrm{a}$ & $8.3 \mathrm{~b}$ & $9.1 \mathrm{c}$ \\
$\quad \begin{array}{l}\text { Mission Vision } \\
\text { REC }\end{array}$ & $6.6 \mathrm{a}$ & $8.3 \mathrm{a}$ & $8.9 \mathrm{~b}$ \\
$\quad \begin{array}{l}\text { Organizational } \\
\text { Structure }\end{array}$ & & $8.7 \mathrm{~b}$ & $9.1 \mathrm{~b}$ \\
\end{tabular}


International Journal of Social Science and Economic Research

ISSN: 2455-8834

Volume:06, Issue:07 "July 2021"

- REC Legality

$6.5 \mathrm{a}$

$7.8 \mathrm{~b}$

$7.6 \mathrm{c}$

The indicators for the legality of the REC which include the perception of the articles of association and by-laws of the REC, the Deed of Establishment of the REC and the declaration of the RECIn this indicator, the results show significant differences in the three research areas.

\section{Cultivation Innovation Perception Difference Test Results}

The results of the different perception test of cultivation innovation between Purbalingga District, Malang District, and Musi Banyuasin District can be seen in table 3. These results indicate that the perception variable of cultivation innovation is significantly different between the three research areas. In this variable, the average of Malang District is the highest compared to Musi Banyuasin District and Purbalingga District.

Farmer perception to technology innovation which was delivered to be the determinant of success in the adoption process of a innovation. Rogers (2003) reported that sooner or later the adoption process of innovation was affected by the characteristic inherence in that innovation. Some characteristics in technology innovation for rice agricultural according to Efendy and Hutapea (2010) viz. complexity of technology innovation, trial ability for utilization, and selective exposure for the farmers needs. The institutional of farmer group (Poktan) was expected to be the proper medium to increase the application of innovation adoption.

\section{Table 3 of Differences in Perceptions of Cultivation Innovations Between Purbalingga and} Malang and Banyuasin Regencies

\begin{tabular}{cccc}
\hline \multicolumn{1}{c}{$\begin{array}{c}\text { Variables And } \\
\text { Indicators }\end{array}$} & $\begin{array}{c}\text { Purbalingga } \\
\text { Mean Score }\end{array}$ & $\begin{array}{c}\text { Malang } \\
\text { Mean Score }\end{array}$ & $\begin{array}{c}\text { Musi } \\
\text { Banyuasin } \\
\text { Mean Score }\end{array}$ \\
\hline $\begin{array}{l}\text { Cultivation } \\
\text { Innovation } \\
-\quad \text { Pre Planting }\end{array}$ & $8 \mathrm{a}$ & $8.7 \mathrm{~b}$ & $6.8 \mathrm{c}$ \\
$\quad \begin{array}{l}\text { Land } \\
-\end{array}$ & $8.2 \mathrm{a}$ & $8.8 \mathrm{a}$ & $7.6 \mathrm{~b}$ \\
$\begin{array}{l}\text { Planting and } \\
\text { Care }\end{array}$ & $8.2 \mathrm{ab}$ & $8.4 \mathrm{ab}$ & $6.7 \mathrm{bc}$ \\
$\begin{array}{l}\text { Harvest and } \\
\text { Post Harvest }\end{array}$ & $7.8 \mathrm{a}$ & $8.9 \mathrm{~b}$ & $6.2 \mathrm{c}$ \\
\hline
\end{tabular}

Soil processing using tractors and the use of organic basic fertilizers and biostimulants are instruments of land pre-planting indicators. Instruments for seeding and transplanting are also 
International Journal of Social Science and Economic Research

ISSN: 2455-8834

Volume:06, Issue:07 "July 2021"

indicators of land pre-planting. Purbalingga District and Malang District have no different perception compared to Musi Banyuasin District.

Indicators of planting and care which include planting with mechanization, direct stocking. Embroidery, use of granular compound fertilizers (inorganic), application of vegetative leaf fertilizers, application of biological fertilizers, generative foliar fertilization and pest and disease control. In this indicator, between Purbalingga District and Malang District, there is no significant difference. Likewise, Malang District and Musi Banyuasin District are also not significantly different. In the harvest and post-harvest indicators, the perceptions were significantly different in the three research areas.

\section{Results of Different Perceptions of REC Performance Test}

The results of the different perception test of REC performance between Purbalingga District, Malang District, Musi Banyuasi District as shown in table 4.

This was in line to research conducted by Yani et al. (2010) that farmer groups as new farming production units play a role in facilitating distribution, but not maximally in facilitating the procurement of production inputs for the group members. Banjarnegara District farmers have been buying their own fertilizer, seeds and pesticides, and have been providing by themselves capital adequacy and labor availability. However, if there was a production input subsidy from the government, farmers could easily obtain such subsidies.

It was in line to the opinion of Wastika et al. (2014) revealed that influencing factors of farmer group's roles in the application of System of Rice Intensification (SRI) were farmer's educational attainment, land holding size, farming experience, attendance frequency and role of farmer's group leaders.

It was in contrast to the research result of Listyati et al. (2014) that farmer groups played a role in improving yield quality, conducting marketing and collaboration to improve the bargaining position and welfare of farmers as producers. Therefore, rice farming institutional in Banjarnegara District must be encouraged to be able to provide added value to surrounding farmers. This was supported by the opinion of Titus and Adefisayo (2012) stating that farmer institutional must be encouraged in creating added value, even in creating new employments.

Table 4 of Differences in Perceptions of REC Performance between Purbalingga and Malang and Banyuasin regencies

\begin{tabular}{llcc}
\hline Variables And Indicators & $\begin{array}{l}\text { Purbalingga } \\
\text { Mean Score }\end{array}$ & $\begin{array}{c}\text { Malang } \\
\text { Mean Score }\end{array}$ & $\begin{array}{c}\text { Musi } \\
\text { Banyuasin } \\
\text { Mean Score }\end{array}$ \\
\hline
\end{tabular}


International Journal of Social Science and Economic Research

ISSN: 2455-8834

Volume:06, Issue:07 "July 2021"

\begin{tabular}{|c|c|c|c|}
\hline \multirow{3}{*}{$\begin{aligned} & \text { Performance } \\
& \text { - } \text { Ability to Identify } \\
& \text { Potential } \\
& \text { - } \text { Ability to Develop } \\
& \text { Marketing }\end{aligned}$} & $7.7 \mathrm{a}$ & $9.1 \mathrm{~b}$ & $8.6 \mathrm{c}$ \\
\hline & $8.0 \mathrm{a}$ & $9.1 \mathrm{~b}$ & $9.2 \mathrm{~b}$ \\
\hline & $7.2 \mathrm{a}$ & $8.9 \mathrm{~b}$ & $7.7 \mathrm{c}$ \\
\hline $\begin{array}{l}\text { - Problem Solving } \\
\text { Ability }\end{array}$ & $8.3 \mathrm{a}$ & $9.5 \mathrm{~b}$ & $9.0 \mathrm{~b}$ \\
\hline $\begin{array}{ll}\text { - } & \text { Ability } \\
& \text { Maintain } \\
\text { Sustainability }\end{array}$ & $7.6 \mathrm{a}$ & $9.3 \mathrm{~b}$ & $8.5 \mathrm{~b}$ \\
\hline
\end{tabular}

The perception of the REC performance variable was significantly different between the research areas and the highest average was in Malang District. There is no difference between the Musi Banyuasi District and Malang District's ability to identify potential indicators. However, both are different from Purbalingga District. The ability to identify potential includes instruments for the need to increase knowledge of appropriate sources of information. The need to increase the ability to use experience for business planning and the need to increase knowledge of the causes of failure or success of the business undertaken.

On the indicator of the ability to develop marketing, it shows the differences between the three research areas. Instruments in this indicator include knowledge of market development information from rice farming production and side businesses. Knowledge of information on the tendency of consumer tastes towards rice farming and side businesses. Knowledge of the latest marketing methods with online social media on rice farming and side businesses.

Indicator of problem solving ability, there is no difference between Malang District and Musi Banyuasin District. However, both are different from Purbalingga District. Instruments in this indicator include knowledge to identify, how to determine the causal factors and appropriate actions to solve problems independently.

The ability to maintain sustainability is one indicator of the REC performance variable where the perception of Purbalingga District is different from that of Malang District and Musi Banyuasin District. The instruments include conserving input factors and yield quality, rice farming partners and side businesses.

\section{Results of Institutional Contribution Models and Cultivation Innovations on REC Performance in Malang District}

The results of the model of the contribution of perceptions of institutional formation and cultivation innovation to the performance of REC in Malang District are as shown in Figure 1. 
Simultaneously, institutions and cultivation innovations have an effect on the performance of REC in Malang District by $63.2 \%$. While partially where the institutional effect is only $12.3 \%$, rice cultivation innovation is $73.6 \%$. The small institutional effect is because the indicators of the term vision and mission are not listed in the model due to their low level as a determining factor. In the REC performance variable, the indicator of problem-solving ability is not a determining factor.

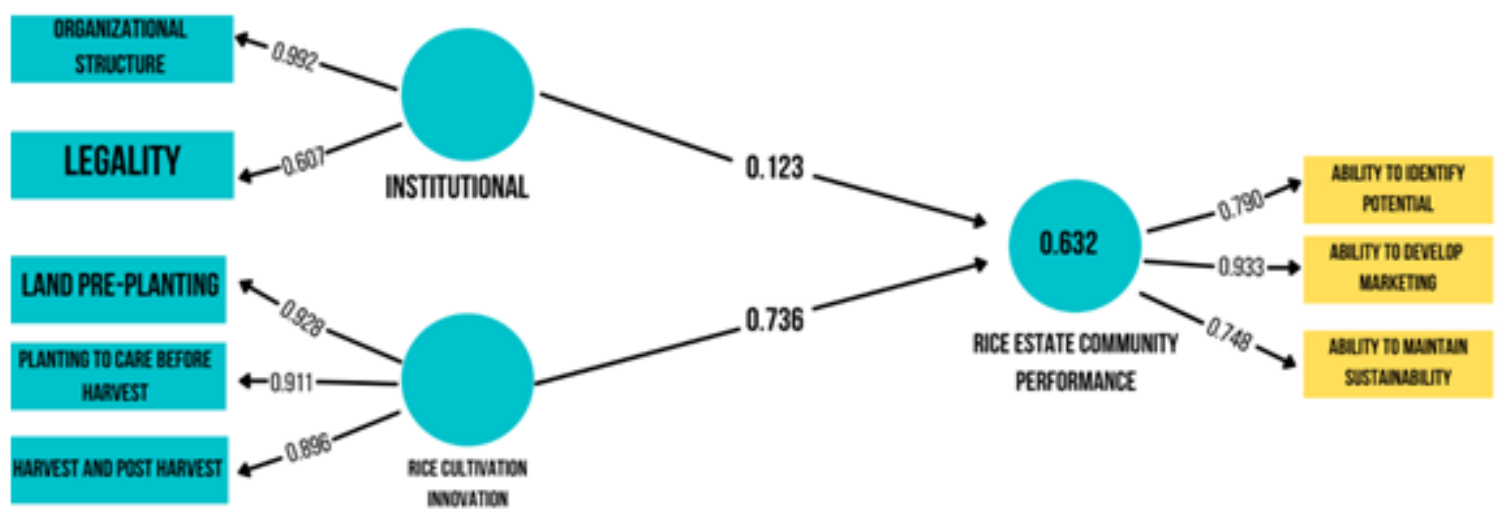

\section{Figure 1. Model of Institutional Contribution and Cultivation Innovation to REC Performance in Malang District}

\section{Results of Institutional Contribution Models and Cultivation Innovations on REC Performance in Purbalingga District}

The results of the model of the contribution of perceptions of institutional formation and cultivation innovation to the performance of REC in Purbalingga District are as shown in Figure 2. Simultaneously, institutions and aquaculture innovations have an effect on the performance of REC in Purbalingga District by $28.3 \%$. While partially where the institutional effect is only $13.5 \%$, rice cultivation innovation is $47.7 \%$. All indicators of institutional formation become determinants of variables. Likewise with the cultivation innovation variable. However, in the REC performance variable, the indicator of the ability to develop markets and maintain sustainability is not a determining factor. 


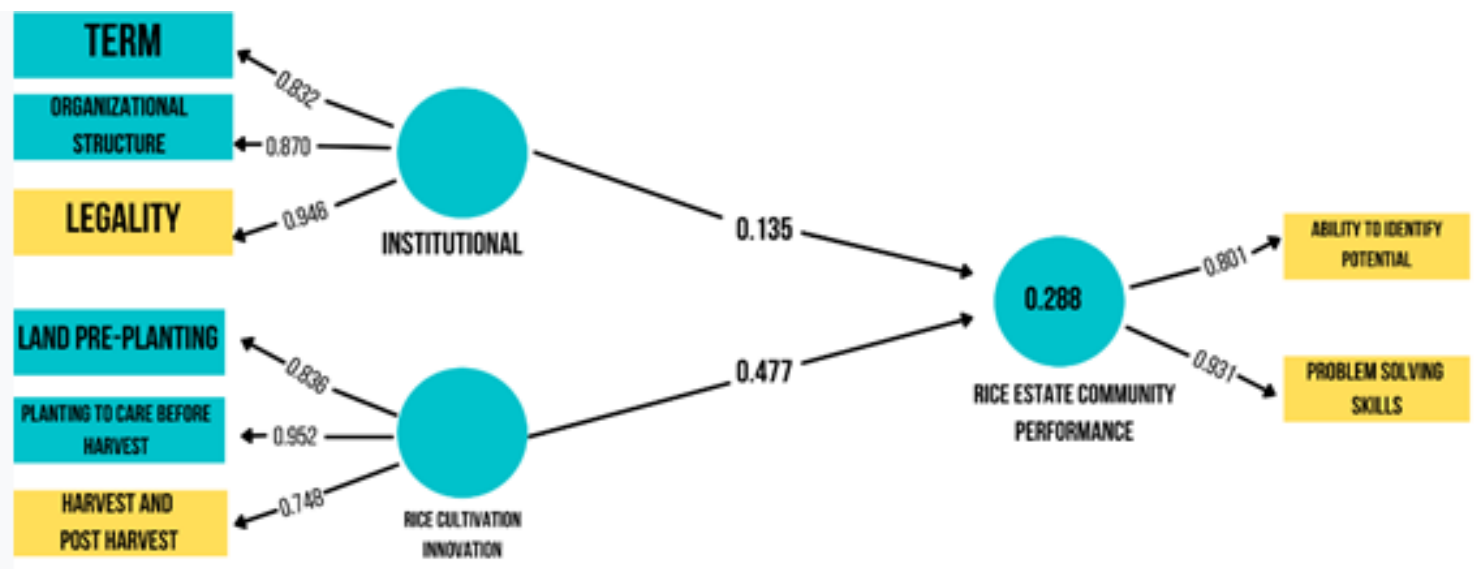

Figure 2. Model of Institutional Contribution and Cultivation Innovation on REC Performance in Purbalingga District

Results of Institutional Contribution Models and Cultivation Innovations on REC Performance in Musi Banyuasin District

The results of the model of the contribution of perceptions of institutional formation and cultivation innovation to the performance of REC in Musi Banyuasi District are as shown in Figure 3. Simultaneously, institutions and cultivation innovations have an effect on the performance of REC in Musi Banyuasin District by $24.9 \%$. While partially where the institutional effect is only $13.5 \%$, rice cultivation innovation is $43.9 \%$. In the indicator of institutional formation, legality is not a determining factor of the variable. Similarly, the variables of cultivation innovation, planting and care indicators are not the determining factors. However, in the REC performance variable, the indicator of the ability to develop the market is not a determining factor.

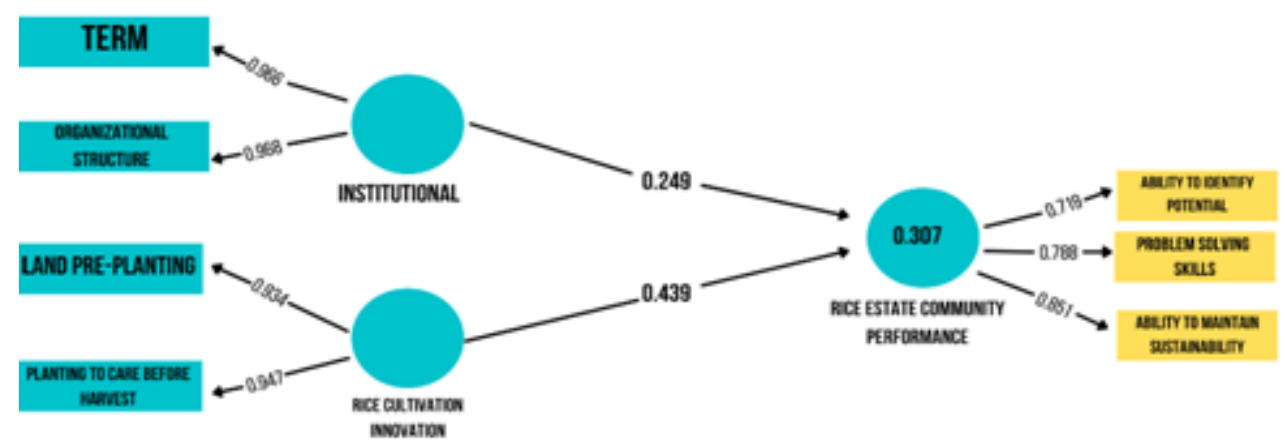

Figure 3. Model of Institutional Contribution and Cultivation Innovation on REC Performance in Musi Banyuasin District 
International Journal of Social Science and Economic Research

ISSN: 2455-8834

Volume:06, Issue:07 "July 2021"

\section{Conclusion}

Perceptions of the formation of REC Institutions in Musi Banyuasin District are better than those of Purbalingga District and Malang District. Perception of Rice Cultivation Innovation in Malang District is better than Purbalingga District and Musi Banyuasin District. Perceptions of the performance of REC, Malang District and Musi Banyuasin District are better than Purbalingga District.

The simultaneous effect of institutional formation and cultivation innovation on REC's performance has the highest contribution in Malang District at 63.2\%. Partially, the institutional effect on the performance of REC has the highest contribution in Musi Banyuasin District, $24.9 \%$. Partially the effect of cultivation innovation on the performance of REC, the highest contribution in Malang District is $73.6 \%$.

\section{Reference}

Andini NK, Nilakusmawati DPE, Susilawati M. (2013). Faktor-faktor yang memengaruhipenduduklanjutusiamasihbekerja.PiramidaJurnalRECendudukandanPengembanga nSumberDaya Manusia.9(1):44-49.

Efendy J, Hutapea Y. (2010). Analysis of Adoption of Agricultural Technology InnovationRicebasedFarminginSumatraintheperspectiveofcommunications.JurnalPengkajiandan Pengembangan TeknologiPertanian. 13(2):119-130.

Ishak E, Siang RD. (2013). Strengthening capacity of fishermen entrepreneurial self throughappropriatetechnologytransfer. J. Manajemen IKM. 10(1):9-16.

Listyati, D., Agus, W. \& Abdul, M.H. 2014. Penguatan kelembagaan untuk peningkatan posisi tawar petani dalam sistem pemasaran Kakao. Jurnal TDIP. 1(1): 15-28.

ManyamsariI,Mujiburrahmad.(2014).Karakteristikpetanidanhubungannyadengankompetensipeta ni lahan sempit.Agrisep.15(2):58-74.

RogersEM.(2003).DiffusionofInnovations.FifthEdition.NewYork(US):TheFreePress.

Seran YL, Kote M, Triastono J. (2011). Peningkatan kapasitas petani jagung melalui uji cobateknologibersamapetanidalammendukungpenguatanpenyuluhanpertanian.ProsidingSeminar Nasional Serealia. Hal:675-683.

Slamet, M. 2002. Kumpulan Bahan Kuliah Kelompok, Organisasi dan RECemimpinan. (tidak dipublikasikan). Bogor (ID): IPB. 
Suyanto S, Khususiyah N. (2006). Imbalan jasa lingkungan untuk pengentasan kemiskinan.

Wastika, C.Y., Sunarru, S.H. \& Subejo. 2014. Peran kelompok tani dalam penerapan SRI (System of Rice Intensification) di Kecamatan Kalikajar Kabupaten Wonosobo. Jurnal Agro Ekonomi. 24(1): 84-93.

Wiyanti EK, Saleh A, Sarwoprasodjo S, Hubeis AVS. (2014). Climate communication on improvement of group capacity. J. Pembangunan. 12(1): 27-33.

Yani,D.E.,Ludivicia,E.S.\&Rinda,N.2010.Persepsianggotaterhadapperan kelompoktanidalammeningkatkankemampuanpenguasaanteknologibudidayaBelimbing.JurnalMa tematika,Sains danTeknologi. 11(2):1-13. 